\title{
CANADIAN CONTEXTS FOR PUBLIC ADVOCACY: BRIEFS AS A GENRE
}

\author{
JANET GRTROW
}

This paper is about one form of public advocacy: the written submissions to government which are called briefs. So it will offer a glimpse of one of the political uses of language in our liberal democracy. And it will offer a glimpse of a phenomenon that's a little harder to keep in sight: the connection between the social profile of a text-its use in the community-and the cognitive profile of the text-the way readers learn from it, and integrate its message with other knowledge. Besides these sightings of democratic uses of language and the social/cognitive profile of the text, my research into the production and reception of briefs has given me a view of genre as a social process by which language users construct situations and formalities. The generic brief is, I believe, still under construction.

My findings, which are still preliminary, have developed from several sources. My inquiry-or my curiosity-began in the classroom, where I was teaching career-programme students how to write briefs. The results of those lessons gave me my first lesson in the brief. Then, four other sources of information contributed:

1. fieldwork-interviews with readers and writers of briefs;

2. analysis of sample briefs;

3. empirical research others have done into the Canadian contexts of advocacy (Pross 1986, 1981; Salter and Salco 1981);

4. theoretical research into genre-mainly Carolyn Miller's article "Genre as Social Action" (1984).

My description of briefs depends on all these sources of information, but I will begin with the last mentioned--Miller's theory of genre. Looking into the brief's generic status, we begin to track down its social life--on what occasions it appears, with whom it associates, how it outfits itself.

Miller analyzes genre as depending on social recognition of types of situations. Over time, members of a community will notice that certain definitions of situational types have been useful in handling certain states of affairs. (Social definitions of consumer credit, for example, enable creditor 
and debtor to conduct their transactions through the monthly statement credit-card users receive and answer to.) These situational types provide the individual with means of making his or her needs known in a way that others know how to respond to. Speech genres depend on this social knowledge and, in turn, instruct speakers in how to express themselves in socially sensible ways: genres tell us how to define our peculiar situations and needs in "socially recognizable and interpretable" ways (158). Without situational regularities, genre will not develop.

Situational regularities seem to abound in brief-writing. The Canadian form of liberal democracy offers a variety of regular channels of communication with decision-makers and policy-makers. These channels range from scheduled presentations to Commissions of Inquiry and Parliamentary Committees on matters of national debate-subsidy, civil rights-to presentations to municipal councils on matters of very local concern-land development, for example, or, even more narrowly, traffic control at an intersection near the presenter's house. Where there are recognized channels of communication, outlined with procedures for utterance, and outfitted with a defined audience, we anticipate that there is also a speech genre which fulfils the conventions of the speech event. All this apparatus of delivery and reception suggests persistent definitions of situations which enable citizens to express individual need as social need. (Re-zoning hearings, for example, define individuals as property owners; in order to make themselves heard, individuals accept this definition and prepare to express themselves in socially sensible ways.) But Miller says that situational regularities are not enough to produce genre. There must be formal regularities as well: that is, it's not enough that, in a community of language users, there is well-distributed knowledge of typical situations-situations like those which define interest groups as needing the attention of government. That would amount only to situational regularity. Formal regularity requires that the users of the genre also know what to say and how to say it, in response to the recognized situation. My research suggests that, while the brief is rich in situational regularities, it's poor in formal regularities.

Sticking with situation for a minute, we'll turn from the audience regularities suggested by invitations from government, and ask who writes briefs. Not just anybody. Only certain actors in the political arena are liable to submit briefs to government. Writing about Canadian "pressure groups," Paul Pross (1981) identifies four stages in the lives of political groups:

1. the initial, "issue-oriented" stage;

2. the "fledgling" stage;

3. the "mature" stage;

4. the "institutionalized" stage. 
He suggests that the "presentation of briefs to public bodies" (231) is likely to be central to the political participation of groups in the second and third stages. At the earliest stage, groups favour "publicity-focussed protests" (231) and at the most developed stage they rely on regular, informal contact with government and PR-based contact with the public. (We will find that these situational definitions are related to formal regularities: certain patterns of group organization generate documents whose structure is efficient in the briefing situation.)

So, if you've got something to say to government, and you and your cohorts have not developed organizational complexity of a certain degree, social definitions predict that you will carry signs in front of the legislature rather than submit a written brief. And if you're a big-wig, and play squash with mandarins, you'll use a genre other than the brief in order to participate in the decision-making activities of government. But these extremes still leave a big social space where we will find political actors whose main address to government is through the established channels which invite written submission.

Who occupies this big social space? Well-organized activitists, clearly. But also consultants, managers, and professionals. These people express their interests in development matters, and they advocate policies and decisions which support professional norms. So students preparing for these roles learn to write briefs in practical-writing classes. When I introduced the brief to my students, they were rather surprised, evidently unaware of situational regularities. They behaved towards the brief as they might have behaved towards a new punctuation mark that their teacher told them actually existed but which they themselves, in all their experience as language users, had never run across. Yet, because they were students, and schooled to accept surprises like this one, they went along with the project.

Unlike my students, I was confident that there were situational regularities-I knew about Commissions of Inquiry and I myself had made submissions to local bodies of government. But I wasn't so confident about formal regularities. How was I going to teach them how to write briefs? I resorted to simplified versions of Aristotelian rhetoric, telling about the classical appeals and the common topics. Soon my students began to produce vehement arguments about pornography, smoking in the workplace, licensing of boaters. But when I tried to imagine a decision-maker attending to these arguments, there seemed to be something wrong. These writers sounded like members of a high-school debating club-aggressive, opinionated, reckless. Later, my interviews with readers of briefs confirmed that I was right in suspecting that these arguments wouldn't do at all in the 
real world, that they would not inspire action and change, that they would not fulfill complex political purposes. Whatever formalities arose from my classroom version of the Aristotelian model, they didn't answer the brief's situational regularities.

In classroom practice, the Aristotelian model discovers the form that will produce the winning argument-the argument which will reduce, supersede, overshadow, humiliate, even eliminate the claims of opponents. And, according to my informants among readers of briefs and according to my own reading of many briefs, it's not only students who seek this kind of formal triumph, but real-world presenters as well. But this classic routing causes no admiration and respect among readers of briefs. Rather it causes dismay, uneasiness, hopes that the brief and its presenters will go away.

And if we look at the brief from the decision-maker's point of view, we can see why this is so: no matter how brilliant the argument, no matter how logically commanding, the text cannot eliminate the opponents themselves-whatever indignity it may impose on their claims. After the presenter's rhetorical triumph, his or her opponents-real-life citizens-are still standing there, unvanquished, probably antagonized rather than humbled by their adversaries' argumentative display. And it's that very adversarialness that unnerves politician and bureaucrat alike. One informant told me that, when a situation develops this degree of conflict, decision-makers will do everything they can to avoid a decision. Canny politicians aren't going to wade into the blood-bath. In fact, the more classically powerful the argument, the less likely it is to move decision-makers to make a decision.

So, what kind of presentation does inspire the commitment and action of the decision-maker? What are the formal regularities which will serve situational regularities? For one thing, the successful brief expresses solidarity with the decision-making body: it articulates an awareness of the constraints on decision-making, namely the decision-maker's accountability to the whole constituency. And, related to this, the successful brief demonstrates good will towards the whole community-not just the immediate audience. And that whole community includes opponents to the presenter's claims. Moreover, the arrangement of the text-its coherence-must provide the reader with a reliable vehicle to other points in the community's ideological map. The brief's internal coherence is politically "logical" only insofar as its contents can be easily integrated into a focal entity-one I will call "consensual definition:-and only insofar as this focal entity intersects with other, highly respectable and unanimous sayings in the political arena. These are the successful brief's most crucial formal characteristics, and I will demonstrate their importance by describing the intervention process as going on at two levels. 
At the first level of intervention, the brief provides the reader-the decision-maker-with consensual definitions for the issues at stake: a consensual definition enables the reader to interpret data in such a way as to make no enemies. I'll give an example of such consensual definition-one from the lobbying the Association of Japanese Canadians has carried on. In its long process of pressuring the federal government for compensation for losses suffered under the War Measures Act, the Association of Japanese Canadians sought, as one member of the group told me, to "construct the language through which the country could understand this issue" (Miki 1987). Although their brief developed a memorable series of typifications and discourse episodes, its peak definition was this one: "democracy betrayed"not "Japanese Canadians betrayed." With this definition they enveloped rather than excluded their opponents, disarming them by embrace rather than attack. And the internal coherence of the document consistently instructs the reader to integrate data into this dominant concept. In turn, this concept intersects the community's whole ideology, making the brief politically logical. So the definition worked: it was adopted by the decisionmakers to whom it was addressed. (One of the authors of the brief told me that he knew the document had been successful when he began to hear his own langauge in the utterances of politicians and media figures.) The definition was adopted because it enabled those decision-makers to talk about the issue in terms which surrounded their whole constituency: it was a consensual definition which corroborated community ideologies-ideologies about fairness and about property, about police powers and especially about petty tyrants.

In the most successful briefings, decision-makers adopt the presenter's issue definition-which brings us to the second level of intervention in the briefing process. Politicians listen or read in the first stage of the briefing process. But we know that mostly politicians talk. And they write. One of my informants, a former federal MP and cabinet minister, repeatedly turned our discussion away from the reading process to his own writing processes: as MP and Minister, he had to generate policy statements, replies to constituents, assertions of his or his office's stance on a great number of issues-thousands of documents in all. The successful brief provides the politician with material for this relentless production of discourse; it provides issue definitions which the decision-maker can retail-in speech or in writingto the community. (One informant, this same federal MP, called these retainable definitions "grabbers.") If the brief cannot generate a new discourse, it cannot sustain a new policy-and the political actor won't touch it. No politician will adopt a policy stance that leaves him speech-less, with no discourse route into the community's ideology. A successful brief provides this route. 
"Grabber" expresses a lay view of the political and cognitive processes surrounding the reception of briefs. Politicians are swamped by a tide of text. So it's no surprise that they value textual coherence--what they called, variously, "grabbers," "internal logic," and "organization." Because of the constraints on their time, and because of the conditions of political survival, the successful brief is not necessarily brief but it is exceptionally tight in its coherence. Every phase must contribute powerfully and conspicuously to a main, useable point. If some segment of text begins to wander, readerly attention changes abruptly-"I put it down," "I begin to skip"-for three reasons. First, reading is requiring too much construction from the text receiver (and he has no time). Second, the reader now knows he's in the presence of an argument he can't use in front of a camera or in a constituency letter or policy statement: the cognitive profile of the text does not match its social use. And, third, the incoherent text-even the marginally incoherent text-comes to stand for a politically negligible entity.

By submitting a textually incoherent brief, the presenters identify themselves as representing a negligible constituency, one that can and will be overlooked. One informant told me that, whereas a disorderly presentation marked by peevishness rather than consensual logic could easily be dismissed, an unfailingly coherent brief is "politically spooky," because what every politician most desires to be associated with and most respects-and fearsis "organization." In a sense, then, we are looking at "textual iconicism"-a term I borrow from Enkvist (1981), who speculates that the arrangement of a text can stand for non-textual experience. The coherence of the brief is an icon of, an index to the coherence and solidarity of the group whose views it expresses. The group which has not developed beyond being an aggregate of common concerns and related grievances has not reached the degree of organizational coherence that enables it to produce a coherent brief, and, accordingly, it has not reached the level of political definition which forces political authorities to take account of it. I have seen, for example, a brief from a "women's group" which claims the attention of the Royal Commission on the Economic Union and Development of Canada on very broad grounds-an ideological re-interpretation of Canadian economic history elaborated by many specific concerns of various sub-interest-groups. The brief is rambling, list-like, sometimes even barely cohesive at sentencelevel. The briefs source was a "collective"-a loose coalition of groups and individuals all feeling resentful about a general category of conditions in Canadian life. I believe that the organizational character of the group, its formation as collective, is directly reflected in the textual features of the brief-failure to establish a strong topic structure or memorable and useable definitions of the issues. The Association of Japanese Canadians' brief, on the other hand, provides a contrary instance of group organization and 
solidarity. The brief's coherence is exceptionally tight, and its consensual definition-"democracy betrayed"-is not only useful to the reader in interpreting each phase of the argument, but also memorable and useful to the political community in orienting itself towards happenings. And, prior to that textual product, unifying group processes first clarified the common ground that defined the association as a political entity: one of the brief's authors told me that the Association's first step was internal; it was a move to "educate the Japanese community" itself on the issues (Miki), to develop a practical political consciousness-and practical political identity. Interestingly, it was this brief writer who told me that government "can't ignore a good brief." And, in contrast, the collective's brief to the Commission on the economy actually concludes by telling the commissioners that the presenters expect their views to be ignored.

I learned from my research that a lot of people write briefs and not very many people know how to do it well. Those we might expect to do it well-planners, developers, engineers, architects, activists-don't do it very well at all: one informant told me that the worst briefs come from "consultants" whose job it is to secure, on their clients' and employers' behalf, the cooperative attention of public decision-makers. This widespread ineptness leads me to think that the brief as genre, despite the spectacle of institutionalized channels of address and reception, is only an emergent form, one whose conventions are still concealed in the rhetorical situation, still waiting to be coaxed out by skilled practitioners.

Along with others, Miller insists that the inventory of genres in a community must be an open set: as the social formation adjusts itself, incorporating new cultural entities and social relations, new typifications of recurrent situations will arise, and new genres will arise. So briefs may be not only a new element in the open set, but an element at the opening of the set, edging only slowly into full membership. And, besides this, Miller maintains that there can be such a thing as a "failed genre claim"-i.e., we may mistakenly assume that generic conventions exist where only certain regularities of form or of situation exist. Formal regularities are slight in briefs, but situational regularities are obvious-the systems of invitational advertisement, agendas, submission processes, formalized response in resolutions, recommendations, policies, laws and bylaws. The abundance of recognizable situational regularities combined with the scarcity of formal regularities may signal that the brief has not yet assumed full generic status in the life of the community.

Miller's definition of genre as "social action" makes genre something that depends on social knowledge about the relation of rhetorical form to 
rhetorical situation: not only must practitioners recognize situational regularities, but they must also know the formal regularities which can address the situation. This may be tacit knowledge for most users of most genres, but it still has to be known, at some level, and widely known. It seems to be this extensive social knowledge that's missing from the brief's career as a genre. If this is so, then the community's experience over time will correct this deficiency, and teaching the genre could play a part in this correction. But Miller's definition of genre as "social action" also makes the genre's life-span and regularities depend on its usefulness in a given social formation. If it's usefulness that's missing, then we're facing a different question. It could be that the real formation of democratic society is not what the generic brief assumes it to be. Perhaps this special kind of textual coherence-the tight, consensual cognitive profile of the successful brief-is not a practical reflection of the real arrangement of interests, conflicts and passions in the democratic community.

\section{WORKS CITED}

"Brief to the Royal Commission on the Economic Union and Development Prospects for Canada" (1983). Submission by Women Against the Budget in conjunction with Women's Research Centre.

Democracy Betrayed (1985). Submission by the National Association of Japanese Canadians to the Government of Canada.

Enkvist, N. (1981). "Experiential Iconicism in Text Strategy." Text, 1, 97111.

Mili, R. (1987). Personal Communication.

Miller, Carolyn (1984). "Genre as Social Action." Quarterty Joumal of Speech, 70, 151-167.

Pross, A. Paul (1986). Group Politics and Public Policy. Toronto: Oxford UP.

Pross, A. Paul (1981). "Pressure Groups: Talking Chameleons." In Canadian Politics in the 1980s, ed. Michael S. Whittington and Glen Williams. Toronto: Methuen. 
Salter, L, and D. Salco (1981). Public Inquiries in Canada. Hull, Quebec: Science Council of Canada.

Owing to assurances of confidentiality, informants from the political scene havewith one exception-not been cited.

Janet Giltrow is a member of the Department of English, Simon Fraser University. 